\title{
OBJEKTIVITAS PEMBERITAAN PESERTA PARTAI POLITIK TAHUN 2009 DALAM PERIODE KAMPANYE PEMILIHAN LEGISLATIF DI KORAN NASIONAL
}

\author{
Ni Ketut Efrata Fransiska \\ Alumnus Jurusan Ilmu Komunikasi, Uiversitas Kristen Petra Surabaya
}

\begin{abstract}
Objectivity is a serving standard of the news that factual and balance. Objectivity of research conducted because little or no coverage entirely objective. Objectivity necessary to be reserached because communication is very easy to stand up for certain parties. Readers or the community will be affected by the content of communication on a mass media. This study will investigate the objectivity of reporting the political parties in 2009 legislative elections during the campaign in a national daily. Results of this research is that the media have not completely objective in their coverage, when viewed from all categories objectivity. With the results, the community or readers can be expected to know the coverage objective.
\end{abstract}

Keywords:Reporting, Content Analysis, Objectivity, Kompas, Jawa Pos, Suara Pembaruan, Media Indonesia.

\section{PENDAHULUAN}

Dengan adanya media massa, informasi bisa disebarkan kepada masyarakat luas. Media massa, seperti radio, televisi, internet, majalah, dan surat kabar, hadir dengan karakteristik yang berbeda dan juga mempunyai target audience yang berbeda. Masing-masing media massa berhak untuk mencari dan menuliskannya dengan cara yang berbeda sesuai kepentingan dan tujuan yang hendak dicapai. Adanya kepentingan pribadi yang berbeda dalam tubuh media massa itu sendiri sangat mempengaruhi bagaimana dan kemana arah pemberitaan dibawa. Selain masalah kepentingan, latar belakang wartawan yang berbeda juga mempengaruhi bagaimana dia memandang sebuah peristiwa yang terjadi, yang juga memungkinkan sebuah berita ditulis dengan komponen yang berbeda.

Salah satu contoh fenomena yang menarik adalah Pemilihan Umum Legislatif Indonesia tahun 2009. Pemilu adalah peristiwa yang penting bagi sebuah negara, karena seluruh kehidupan di negara tersebut sangat tergantung dari kebijakankebijakan partai politik yang menang dalam Pemilu Legislatif. Menurut UU No. 10 Tahun 2008 tentang Pemilu menyebutkan bahwa Pemilihan Umum, selanjutnya disebut Pemilu, adalah sarana pelaksanaan kedaulatan rakyat yang dilaksanakan secara langsung, umum, bebas, rahasia, jujur, dan adil dalam Negara Kesatuan Republik Indonesia berdasarkan Pancasila dan Undang-Undang Dasar Republik Indonesia Tahun 1945. Dan Pemilu Legislatif adalah Pemilihan Umum dimana rakyat bisa memilih wakil-wakilnya (DPD, DPRD, dan DPR) secara langsung. 
Pada Pemilu 2004, partai-partai besar mendapat porsi pemberitaan lebih banyak. Partai-partai tersebut antara lain Partai Demokrasi Indonesia Perjuangan (PDIP), Partai Golkar, Partai Persatuan Pembangunan (PPP), dan Partai Amanat Indonesia (PAN) (Dominasi Partai Besar, 2009, p.2). Begitu juga awal-awal masa kampanye Pemilu Legislatif 2009, partai-partai besar lebih banyak diberitakan di harian cetak surat kabar dari pada partai kecil. Partai-partai besar yang diberitakan meliputi Partai Golkar (Golongan Karya), PDIP (Partai Demokrasi Indonesia Perjuangan), PAN (Partai Amanat Nasional), PPP (Partai Persatuan Pembangunan), PKB (Partai Kebangkitan Bangsa), PKS (Partai Keadilan Sosial), dan PD (Partai Demokrat). Sebanyak empat puluh empat partai politik akan ikut serta dalam Pemilu 2009 (Sari, 2008, p.9). Hampir sama dengan Pemilu 2004, pemberitaan Pemilu Legislatif 2009 juga didominasi oleh partai-partai besar seperti, Partai Golkar, PDIP, PAN, PKS, PPP, PKB, dan Partai Demokrat.

Penelitian ini ingin melihat pemberitaan pada partai yang berhasil melewati Electoral Threshold pada pemilu 2004, yaitu partai yang memperoleh sekurangkurangnya tiga persen jumlah kursi DPR dan itu merupakan syarat untuk mengikuti pemilu berikutnya. Partai-partai politik tersebut antara lain, Partai Golkar, PDIP Perjuangan, Partai Kebangkitan Bangsa, Partai Persatuan Pembangunan, Partai Demokrat, Partai Keadilan Sejahtera, dan Partai Amanat Nasional (Electoral Threshold, 2004, p. 2). Disamping karena melewati Electoral Threshold, ketujuh partai ini dipilih karena pemberitaannya pada media cetak surat kabar mendapat porsi lebih banyak daripada partai-partai lainnya.

Pemberitaan partai politik di media massa akan membawa pengaruh bagi pembacanya, dan tidak mustahil hal tersebut juga akan berpengaruh pada pilihan suara yang akan dijatuhkan pada pemilu nanti. Selama ini banyak tindakan negatif yang dilakukan wakil-wakil rakyat yang turut menyeret nama partai politik ke arah negatif, seperti kasus suap Al Amin Nasution, kasus korupsi Agus Condro, atau kasus perselingkuhan dan pelecehan seksual oleh anggota dewan. Hal-hal tersebut berpotensi untuk menurunkan simpati masyarakat pada individu maupun parpol yang bersangkutan.

Pada sebuah pemberitaan di surat kabar Kompas, Presiden Republik Indonesia, Susilo Bambang Yudhoyono (SBY) diberitakan menyampaikan keberhasilannya selama hampir lima tahun memimpin sebagai presiden dalam kampanyenya di Jakarta (SBY Sampaikan Keberhasilannya, 21 Maret 2009). Dalam berita tersebut, yang menjadi nara sumber satu-satunya adalah SBY. Sehingga apabila dilihat dari kategori cover both sides, berita ini tidak objektif karena yang menjadi nara sumber dalam pemberitaan itu hanya dari satu pihak, yaitu SBY.

Contoh berita lain yang dikutip dari surat kabar Media Indonesia menyebutkan, "Upaya mencegah pelibatan anak dalam kampanye dilakukan Partai Keadilan Sejahtera (PKS) di Lapangan Gasibu Bandung, Jawa Barat, kemarin, tidak berjalan optimal. Padahal PKS sengaja membangun tenda penitipan anak agar anak-anak bebas dari kampanye" (Parpol Sulit Cegah Anak dalam Kampanye, 30 Maret 2009, p.1). Terdapat opini wartawan dalam paragraf tersebut, ditandai dengan adanya kata "padahal". Dengan demikian, berita ini tidak objektif dilihat dari kategori pencampuran fakta dan opini.

Berdasarkan dua gejala tersebut, peneliti ingin meneliti lebih dalam lagi mengenai sejauh mana tingkat objektivitas pemberitaan partai politik selama masa 
kampanye pada media cetak surat kabar. Peneliti memilih topik objektivitas pemberitaan, karena tidak ada pemberitaan yang benar-benar objektif. Berdasarkan latar belakang yang telah diuraikan, perumusan masalah dalam masalah ini adalah "Bagaimana objektivitas pemberitaan partai politik peserta Pemilu Legislatif 2009 selama massa kampanye massal pada harian Kompas, Jawa Pos, Suara Pembaruan, dan Media Indonesia?". Adapun tujuan dari penelitian ini adalah untuk mengetahui bagaimana objektivitas pemberitaan partai politik peserta Pemilu Legislatif 2009 selama masa kampanye massal pada harian Kompas, Jawa Pos, Suara Pembaruan, dan Media Indonesia.

\section{Konsep Objektivitas}

Menurut Hidayat (dalam Siahaan, et al., 2001, p. 62) kritik mendasar terhadap usaha mendefinisikan dan meneliti konsep objektivitas selama ini, terutama, adalah anggapan: "....there is no objective reality 'out there' to report on: the best we can expect is no more than different versions of a multi various set of impressions". Lebih dari itu, Glasser (1984) menilai objektivitas pemberitaan sebenarnya merupakan suatu ideologi, yang dengan demikian merupakan bias terhadap berfungsinya the watching role of the press, pemikiran bebas, dan tanggung jawab pers. Namun pendapat yang menengahi antara mereka yang pro dan kontra objektivitas pemberitaan menyatakan, pemberitaan pers tidak perlu harus objektif. Pers harus berpihak pada nilai-nilai tertentu, terutama yang berkaitan nilai-nilai kepentingan masyarakat. Tapi opini atau kritik terhadap suatu keadaan yang dinilai tidak sesuai nilai-nilai tertentu tadi perlu didasarkan data dan pengetahuan yang seobjektif mungkin.

Objektivitas adalah penyajian berita yang benar, tidak berpihak, dan berimbang. Indikator yang digunakan adalah dimensi truth (yakni tingkatan sejauh mana fakta yang disajikan benar atau bisa diandalkan/reliable); relevansi (yakni tingkatan sejauh mana relevansi aspek-aspek fakta yang diberitakan dengan standar jurnalistik/newsworthiness); dan ketidakberpihakan (impartiality)-yakni tingkatan sejauh mana fakta-fakta yang diberikan bersifat netra dan berimbang (Siahaan, et al., 2001, p.100).

Objektivitas adalah metode yang dipakai untuk menghadirkan suatu gambaran dunia yang sedapat mungkin jujur dan cermat dalam batas-batas praktik jurnalistik. Menurut Siregar dan Surjana terlepas dari perdebatan tak pernah selesai itu, menurut Daniel Dhakidae, persoalannya bagaimana pers bisa menarik garis yang keras antara opini dan fakta; pendapat dan berita; yang benar terjadi dan pendapat redaktur atau siapapun yang dimuat di surat kabar. Pertanyaan yang muncul, pada benar ada bagian yang semata-mata opini dan bagian lain yang seluruhnya fakta? Karenanya, perlu ditarik garis di mana fakta berakhir dan opini dimulai. Untuk membuat guide line yang tegas merupakan soal besar yang menyangkut desain, cara me-manage dan planning ataupun manajemen rubrik (dalam Siahaan, et al., 2001. p.63).

J. Westerstahl pada tahun 1983 mengembangkan kerangka konseptual dasar bagi meneliti dan mengukur objektivitas pemberitaan, yang kemudian dirinci lebih lanjut oleh McQuail. Berikut kerangka objektivitas yang telah dirinci lebih lanjut oleh McQuail (Siahaan, et al., 2001). 


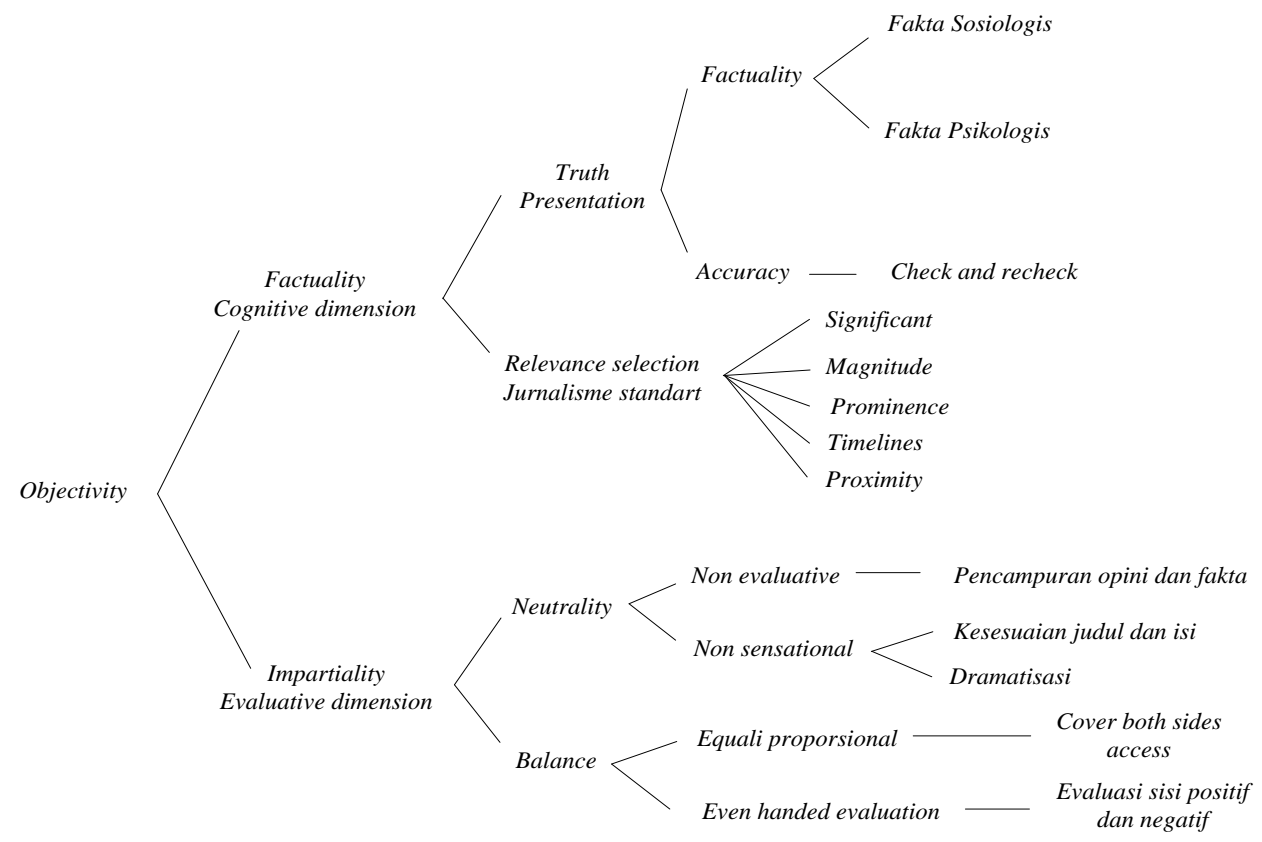

Sumber: Imawan, Teguh, Jacky, M., Purnomo, Tjahjo., \& Siahaan, Hotman (2001, p.69)

\section{Gambar 1. Skema Kerangka Objektivitas}

Objektivitas pemberitaan adalah penyajian berita yang benar, tak berpihak dan berimbang. Indikator yang digunakan adalah dimensi truth (yakini tingkatan sejauh mana fakta yang disajikan benar atau bisa diandalkan/reliabel); relevansi (yakni tingkatan sejauh mana relevansi aspek-aspek fakta yang diberitakan dengan standar jurnalistk/newsworthiness); dan ketidakberpihakan (impartiality)-yakni tingkatan sejauh mana fakta-fakta yang diberitakan bersifat netral dan berimbang.

Menurut Siahaan, et al., (2001, p.100-102), objektivitas pemberitaan diukur dengan indikator-indikator:

\section{Dimensi truth:}

a. Sifat fakta (factualness), adalah sifat fakta bahan baku berita, yang terdiri dari dua kategori:

1. Fakta sosiologis adalah pemberitaan yang bahan bakunya berupa peristiwa/ kejadian nyata/faktual

2. Fakta psikologis adalah berita yang bahan bakunya berupa interpretasi subjektif (pernyataan/opini) terhadap fakta kejadian/gagasan.

b. Akurasi adalah kecermatan atau ketepatan fakta yang diberitakan. Indikator yang digunakan adalah check and recheck, yakni mengkonfirmasi/menguji kebenaran dan ketepatan fakta kepada subjek, objek, atau saksi berita sebelum disajikan. 


\section{Relevansi}

Relevansi dengan standar jurnalistik adalah relevansi aspek-aspek fakta dalam berita dengan indikator kelayakan berita (newsworthiness), yakni significance, magnitude, prominance, timeliness, dan proximity (geografis dan psikologis).

a. Significance adalah fakta yang mempengaruhi kehidupan orang banyak atau berakibat terhadap kehidupan khalayak pembaca.

b. Prominence adalah keterkenalan fakta/tokoh.

c. Magnitude adalah besaran fakta yang berkaitan dengan angka-angka yang berarti, atau fakta yang berakibat bisa dijumlahkan dalam angka yang menarik bagi pembaca.

d. Timeliness adalah fakta yang baru terjadi atau diungkap.

e. Proximity geografis adalah fakta kejadian yang lokasinya dekat dengan tempat tinggal mayoritas khalayak pembaca.

f. Proximity psikologis adalah fakta kejadian yang memiliki kedekatan emosional dengan mayoritas khalayak pembaca.

\section{Ketidakberpihakan}

Ketidakberpihakan (impartiality) adalah tingkatan sejauh mana evaluasi subjektivitas (penilaian, interpretasi, dan opini pribadi) wartawan tak terlibat dalam memproses fakta menjadi berita. Indikator yang digunakan:

a. Netralitas adalah tingkatan sejauh mana sikap tak memihak wartawan dalam menyajikan berita. Netralitas diukur dengan indikator:

1. Pencampuran opini dengan fakta adalah opini/pendapat pribadi wartawan masuk ke dalam berita yang disajikan.

2. Kesesuaian judul dengan isi adalah kesesuaian substansi judul berita dengan isi/tubuh berita.

3. Dramatisasi adalah penyajian fakta secara tidak proporsional sehingga memunculkan kesan berlebihan (menimbulkan kesan ngeri, kesal, jengkel, senang, simpati, antipati, dan sejenisnya).

b. Balance adalah keseimbangan dalam penyajian aspek-aspek evaluatif (pendapat, komentar, penafsiran fakta oleh pihak-pihak tertentu) dalam pemberitaan. Balance diukur dengan indikator:

1. Cover both sides adalah menyajikan dua/lebih gagasan/tokoh atau pihak-pihak yang berlawanan secara bersamaan dan proporsional.

2. Nilai imbang (even handed-evaluation) adalah menyajikan evaluasi dua sisi (aspek negatif dan positif) terhadap fakta maupun pihak-pihak yang menjadi berita secara bersamaan dan proporsional.

\section{METODE PENELITIAN}

Pada penelitian ini peneliti menggunakan metode analisis isi kuantitatif. Perhitungan presentase mengenai objektivitas pemberitaan partai politik peserta Pemilu Legislatif 2009 di surat kabar Kompas, Jawa Pos, Suara Pembaruan, dan Media Indonesia. Peneliti juga melakukan uji realibitas kategori dengan mengguna- 
kan rumus Ole R. Holsty. Peneliti disini melakukan pretest dengan cara mengkoding sampel kedalam konstruksi kategori milik Dennis McQuail.

Teknik pengumpulan data yang digunakan dalam penelitian ini adalah mengumpulkan dokumentasi berita-berita partai politik peserta Pemilu Legislatif 2009 dari surat kabar Kompas, Jawa Pos, Suara Pembaruan, dan Media Indonesia mulai tanggal 17 Maret 2009 sampai dengan 6 April 2009. Berita yang dikumpulkan oleh peneliti dalam penelitian ini adalah semua jenis berita, straight news dan feature.

Analisis data menggunakan kategorisasi. Kategorisasi dalam analisis isi merupakan instrumen pengumpul data. Fungsinya identik dengan kuesioner dalam survei. "Supaya objektif, maka kategorisasi harus dijaga realibilitasnya. Terutama untuk kategorisasi yang dibuat sendiri oleh periset sehingga belum memiliki standar yang teruji, maka sebaiknya dilakukan uji realibilitas.

\section{PEMBAHASAN}

Tabel 1 ini menggambarkan mengenai perbandingan secara kuantitas objektivitas empat surat kabar yang telah ukur dengan menggunakan analisis isi.

Tabel 1. Perbandingan Objektivitas

\begin{tabular}{|c|c|c|c|c|c|c|c|c|}
\hline \multirow{3}{*}{$\begin{array}{l}\text { Kategori Objektivitas } \\
\text { 1. Truth }\end{array}$} & \multicolumn{8}{|c|}{ Surat Kabar } \\
\hline & \multicolumn{2}{|c|}{ Kompas } & \multicolumn{2}{|c|}{ Jawa Pos } & \multicolumn{2}{|c|}{$\begin{array}{c}\text { Suara } \\
\text { Pembaruan }\end{array}$} & \multicolumn{2}{|c|}{$\begin{array}{c}\text { Media } \\
\text { Indonesia }\end{array}$} \\
\hline & Fr & $\%$ & Fr & $\%$ & $\mathrm{Fr}$ & $\%$ & $\mathrm{Fr}$ & $\%$ \\
\hline Fakta Sosiologis & 7 & 41.17 & 22 & 46.8 & 10 & 29.41 & 1 & 4.16 \\
\hline Fakta Psikologis & 10 & 58.83 & 25 & 53.2 & 24 & 70.59 & 23 & 95.84 \\
\hline \multicolumn{9}{|l|}{ 2. Akurasi } \\
\hline Check and Recheck & 17 & 100 & 47 & 100 & 34 & 100 & 24 & 100 \\
\hline \multicolumn{9}{|l|}{ 3. Relevansi } \\
\hline Significance & 3 & 17.64 & 1 & 2.12 & 3 & 8.83 & 5 & 20.83 \\
\hline Prominance & 14 & 82.36 & 27 & 57.44 & 23 & 67.64 & 18 & 75 \\
\hline Magnitude & 0 & 0 & 13 & 27.65 & 5 & 14.7 & 1 & 4.17 \\
\hline Timeliness & 0 & 0 & 1 & 2.12 & 0 & 0 & 0 & 0 \\
\hline Proximity & 0 & 0 & 5 & 14.91 & 3 & 8.83 & 0 & 0 \\
\hline \multicolumn{9}{|l|}{ 4. Neutrality } \\
\hline Pencampuran Opini dan Fakta & 0 & 0 & 16 & 34.04 & 1 & 2.94 & 1 & 4.16 \\
\hline \multicolumn{9}{|l|}{ 5. Neutrality Non-sensational } \\
\hline Judul Sesuai dengan Isi & 17 & 100 & 47 & 100 & 34 & 100 & 24 & 100 \\
\hline Ada Dramatisasi & 0 & 0 & 2 & 5.88 & 1 & 2.94 & 0 & 0 \\
\hline \multicolumn{9}{|l|}{ 6. Equali Proportional } \\
\hline Cover both sides & 9 & 52.94 & 17 & 36.17 & 22 & 64.7 & 10 & 41.66 \\
\hline \multicolumn{9}{|l|}{ 7. Even Handed Evaluation } \\
\hline Nilai Imbang & 17 & 100 & 40 & 85.10 & 25 & 73.52 & 18 & 75 \\
\hline
\end{tabular}


Sumber: Kompas, JawaPos, Suara Pembaruan, Media Indonesia, tanggal 17 Maret - 6 April 2009

Tabel 1 menunjukkan jumlah objektivitas keempat surat kabar dalam pemberitaan partai politik selama masa kampanye, yang dilihat dari faktualitas dimensi kognitif (factualness, akurasi, relevansi), dan imparsialitas dimensi evaluatif (neurality non evaluative, neutrality non sensational, equali proportional, even handed evaluation).

Berdasarkan kategori truth, surat kabar Jawa Pos merupakan suat kabar dengan objektivitas paling tinggi daripada yang lain. Hal tersebut ditunjukkan dengan angka persentase pada fakta psikologis lebih kecil daripada ketiga surat kabar yang lain, yaitu $46.8 \%$ atau 22 dari 47 berita. Sedangkan surat kabar dengan fakta sosiologis terendah adalah Media Indonesia, yang sekaligus memiliki fakta psikologis dengan persentase terbesar, yaitu $95.84 \%$, atau 23 dari 24 beritanya. Dari kategori akurasi, semua surat kabar melakukan check and recheck pada seluruh beritanya. Kategori berikutnya, yaitu relevansi, Kompas paling banyak mengandung nilai berita prominance sebesar $82.36 \%$, kemudian dilanjutkan dengan nilai berita significance dengan persentase $17.64 \%$. Kompas tidak mengandung magnitude, timelines, dan proximity. Sedangkan Jawa Pos juga paling banyak mengandung nilai berita prominance dengan persentase $57.44 \%$, disusul dengan magnitude dengan persentase $27.65 \%$. Nilai berita berikutnya yang terdapat dalam Jawa Pos adalah Proximity sebesar $14.91 \%$, dan significance dan timeliness masing-masing sebesar $2.12 \%$. Pada Suara Pembaruan, nilai berita yang paling dominan adalah prominance dengan persentase sebesar 67.64\%, kemudian magnitude sebesar 14.7\%, kemudian significance dan proximity masing-masing sebesar $8.83 \%$. Pada surat kabar Media Indonesia, nilai berita yang paling sering muncul adalah prominance dengan persentase $75 \%$, disusul dengan significance sebesar $20.83 \%$, dan magnitude sebesar 4.17\%. Dengan demikian, semua berita mengandung news value sehingga semua berita dari empat surat kabar dikatakan objektif.

Dalam Neutrality, surat kabar Kompas tidak ada melakukan pencampuran opini dan fakta sama sekali pada seluruh beritanya, sehingga dari kategori ini Kompas paling objektif. Sedangkan Jawa Pos paling sering melakukan pencampuran opini dan fakta yaitu sebanyak 16 kali atau dengan persentase $34.04 \%$. Dilihat dari Neutrality Non-sensational kategori kesesuaian judul dan isi berita, seluruh berita pada keempat surat kabar sudah sesuai dengan judul pada berita tersebut, dimana hal tersebut berarti semua surat kabar objektif. Dari kategori dramatisasi, Kompas dan Media Indonesia sama sekali tidak mengandung dramatisasi pada seluruh beritanya. Sebaliknya, Jawa Pos paling banyak memasukkan unsur dramatisasi pada beritanya, yaitu sebanyak 2 kali atau dengan persentase $5.88 \%$. Dengan demikian, Kompas dan Media Indonesia dari kategori ini paling objektif.

Dari kategori Equali Proportional (cover both sides) Kompas melakukan cover both sides sebesar 52.94\%, Jawa Pos sebesar 36.17\%, Suara Pembaruan sebesar 64.7\%, dan pada Media Indonesia sebesar 41.66\%. Berdasarkan kategori ini, Jawa Pos paling objektif. Dari kategori even handed evalution (nilai imbang) hanya Kompas yang melakukannya sebesar 100\%. Surat kabar lainnya, yaitu Jawa Pos mengandung nilai imbang hanya sebesar $85.10 \%$ atau 40 dari 47 beritanya. Pada Suara Pembaruan nilai imbang terdapat sebesar $73.52 \%$ atau hanya 25 berita dari 
total 34 berita. Dan pada Media Indonesia nilai imbang hanya terkandung sebesar $75 \%$ atau hanya 18 berita dari 24 beritanya yang mengandung nilai imbang. Berdasarkan hasil tersebut, maka dari kategori ini Kompas paling objektif.

Berdasarkan kategori objektivitas yang terdiri dari dimensi faktual (factual)dan berimbang (impartiality) maka tingkat objektivitas media mempengaruhi kualitas berita dan secara tidak langsung akan mempengaruhi kinerja dari media sebuah media (McQuail, 1992, p.10-12). Diurutkan berdasarkan kategori dari objektivitas, maka kinerja media terbaik dilihat dari kategori Truth, Jawa Pos memiliki kinerja tertinggi daripada tiga media lainnya. Dari kategori Akurasi (check and recheck) dan Relevansi (relevance), keempat media (Kompas, Jawa Pos, Suara Pembaruan, Media Indonesia) memiliki kinerja yang baik. Dari kategori Neutrality (pencampuran opini dan fakta), Kompas memiliki kinerja terbaik. Kemudian dari kategori Neutrality NonSensational Kesesuaian Isi dan Judul, keempat media memiliki kinerja yang baik karena seluruh isi berita yang terdapat pada keempat media sesuai dengan judul yang dipilih. Dari kategori Neutrality Non-Sensational Dramatisasi, Kompas dan Media Indonesia sama-sama memiliki kinerja yang baik karena tidak menuliskan kata-kata yang mengandung unsur dramatisasi dalam pemberitaannya. Dari kategori Equali Proportional (Cover Both Sides), Kompas memiliki kinerja yang paling baik di antara tiga media lainnya. Dan dari kategori Even Handed Evaluation (Nilai Imbang), kinerja tertinggi juga dilakukan Kompas, dengan cara memberitakan sisi positif dan negatif secara proporsional pada setiap pemberitaan yang dilakukan.

\section{DAFTARPUSTAKA}

Amri, Arfi Bambani., Setiawan, Aries. 23 Februari 2009. Demokrat luncurkan bravo media center. Vivanews. Retrieved May 10, 2009 from http://politik.vivanews. com/news/read/32879-demokrat_luncurkan_bravo_media_center

B dari ensiklopedia pers Indonesia (EPI). 2008, November 14). PWI. Retrieved March 17, 2009 from http:/pwi.or.id/index.php/Pressedia/B-dari-Ensiklopedi-Pers-IndonesiaEPI.html.

Bungin, Burhan. 2001. Metode penelitian kalitatif aktualisasi metodologis ke arah ragam varian kontemporer. Jakarta: PT RajaGrafindo Persada.

Budiarjo, Miriam. 1994. Demokrasi di Indonesia. Jakarta: PT Gramedia Pustaka Utama.

Dominasi partai besar. (n.d.). Retrieved March 17, 2009 from http://www.isai.or.id/?q= node/40

Electoral threshold. 2004, May 7. Tempo Interaktif. Retrieved March 1, 2009 from http://www.tempointeraktif.com/hg/narasi/2004/05/07/nrs,20040507-01,id.html

Hamad, Ibnu. 2004. Konstruksi realitas politik dalam media massa. Jakarta: Granit.

Hamad, Ibnu., Sudibyo, Agus., \& Qodari, Muhammad. 28 mei 2001. Provokasi media massa. Kompas Cyber Media. Retrieved September 3, 2008 from http://www2. kompas.com/kompas-cetak/0105/28/DIKBUD/prov28.htm.

Iskan, Dahlan. 25 April 2009. SBY-JK; Memuaskan dan tidak memuaskan. Wordpress. Retrieved June 15, 2009 from http://dahlaniskan.wordpress.com/ 2009/ 
Imawan, Teguh., Jacky, M., Purnomo, Tjahjo., \& Siahaan, Hotman. 2001. Pers yang gamang studi pemberitaan jajak pendapat Timor Timur. Surabaya: Lembaga Studi Perubahan Sosial.

Krippendorff, Klaus. 2004. Analisis isi: Pengantar dan metodelogi. Jakarta: Rajawali Pers.

Kriyantono, Rachmat. 2006. Teknik praktis riset komunikasi. Jakarta: Kencana Media Group.

McQuail, Dennis. 1992. Media performance. London: SAGE Publication.

Nazir, Mohammad. 1985. Metode penelitian. Jakarta: Ghalia Indonesia.

Nugroho, Bimo. 1999. Politik media mengemas berita. Jakarta: Institut Studi Kasus Informasi.

Rahardiansah, Trubus. 2008. Pengantar ilmu politik konsep dasar, paradigma, dan pendekataannya. Jakarta: Penerbit Universitas Trisakti.

Sasi, Adinda S. 2007. Pencitraan Departemen Agama oleh Harian Kompas dan Republika dalam kasus jamaah haji kelaparan. (TA No.10010209/KOM/2007). Unpublished undergraduate thesis, Universitas Kristen Petra, Surabaya.

Singarimbun, Masri., Sofian, Efendi. 1983. Metode penelitian survei. Jakarta: LP3ES.

Suhandang, Kustadi. 2004. Pengantar jurnalistik. Bandung: Yayasan Nuansa Cendekia.

Saptaatmaja, Tom. 27 Januari 2009. Imlek dan panggilan politik bagi etnis Tionghoa. Surabaya Post. Retrieved February 29, 2009 from http://www.surabayapost. co.id/?mnu=berita\&act=view\&id=79e0effe60c1d4c057037f430cd25b73\&je nis $=\mathrm{d} 645920 \mathrm{e} 395$ fedad7bbbed0eca3fe2e0\&PHPSESSID $=\mathrm{a} 27 \mathrm{~b} 84 \mathrm{a} 7 \mathrm{cc} 531$ $6 \mathrm{e} 512 \mathrm{~b} 71 \mathrm{e} 32 \mathrm{fbf} 7 \mathrm{a} 3 \mathrm{c} 6$

Sari, Heppy R., 13 Juli 2008. Masa kampanye panjang pemilu legislatif dimulai. Antara News. Retrieved April 26, 2009 from http://www.antara.co.id/arc/2008/ 7/13/masa-kampanye-panjang-pemilu-legislatif-dimulai/ 